\title{
Alienation from democratic process: A Case Study of Munda People in Tripura, North East India
}

\author{
Satyajit Das \\ Assistant Professor of Pol-science, Government Degree College, Dharmanagar,Tripura
}

\begin{abstract}
It has already been well approved by many political scientist, theorists, thinkers that democracy is the more effective form of government for its unique nature and features. In every democratic society, people can directly involved in democratic processes like participation in decision making of government, take part in franchise, and express their opinion. The constitution of India also deals with the rights and duties of the citizens. No one can restrict or prohibits anyone from enjoying or exercising those rights. In Tripura, out of 19 tribes, Munda tribe is one of the important migrated tribes. Since their migration in Tripura, they have been deprived of their requirements in many ways; sometimes their rights are overlooked. As a result of that they are alienated from democratic processes in fact from their basic rights and needs. The present paper intends to explore how Munda people of Tripura are alienated from democratic process and find out the way of their active participation in the democratic process.
\end{abstract}

Key words: Alienation, democratic process, Munda tribe, North East India, Tripura

\section{Introduction}

The root meaning of alienation denoted a relationship to property one could for example, alienate ones property by transferring it to another person, on to an institution. During the seventeenth century, the focus of the term shifted from material to immaterial possessions such as rights and sovereignty over oneself (McLean \& McMilan-2009). It came to be accepted by thinkers such as Grotius and Locke that alienating certain rights or powers was a necessary prerequisite for legitimate political society. Alienation in this sense became the basis of social contract theory.

Later on Hegel and Marx also explained the terms in their own point of view. According to Hegel the purpose of history to be the progressive overcoming of the gap between the particular consciousness and the universal consciousness until a final unity of the two is achieved (absolute self consciousness). For Marx, the superseding of capitalism is a necessary prerequisite for ridding alienation of its distorted elements (McLean \& McMilan-2009).

The term 'democratic process' denotes many important things. Apparently it means the process of democracy under which people of the society are equipped in such a way that they all trying to take part in the developmental works through the means of democracy. But if we look into the democratic states throughout the globe, we usually noticed that all the states or their government making welfare policy for their citizens and to protect their rights. Therefore, people of a society enjoy all the freedom and rights what they deserve and the government of every democratic states also working accordingly.

India has a long history of its democratic structure. Before the independence many political thinkers, social reformer, politician dreamt for a better Indian society where the people will surely fulfill there basic needs and requirements. For that they fought against the British rule and tried to protect their democratic rights. After getting Independence on $15^{\text {th }}$ august 1947, the constituent assembly was formed and after a long period of time Indian constitution was made by it. In this constitution, it has been mentioned that India is a democratic country. To make this term fruitful in actual sense, the framers of Indian constitution enlisted many provisions for the betterment of the people. They were also gave a great emphasis on democratic process because it is an instrument by which the notion democracy may be achieved its goal and people will not suffer in any circumstances.

But in India the people are divided into different communities. People of each community are to some extent deprive from their basic needs and requirements. One such community is Munda community. They are the typical tribal community of India. But in respect of Tripura they are migrated from Chotonagpur, Jharkhand, and Orissa to Tripura. In the reign of Maharaja Birendra Kishore Manikya Bahadur who was regarded as the chief exponent of initiation of modernization in Tripura, and that time in 1916, the Munda people came to Tripura for their livelihoods.

Since the introduction of tea gardens in Tripura, the more essential demand of the day was workers as they gave their labor to the tea garden and ultimately tea will be produced. From that point of corner the Munda tribe were brought into Tripura along with Santhal, Bhil and Oraon. It must be noted here that although the 
Munda people are migrated but they had their own history for coming into Tripura. Actually it has been recognized by every one that the Munda people of Chotonagpur plateau or Jharkhand region were lived a miserable life. Their social and economic condition was poor. They fully depend on hunting or agriculture. For that it became a tough job for a family member to fulfill the demands of their family. Pressure from the family members, the male counterparts of the family were searching for job every where. At that time the tea garden authority of Assam has provoked them by saying that we shall take you away to a place where the tree will produce gold when you shake it. The simple and laborious Munda people thought it would be good for them as well as their family members. After that they were agreed to come with them along with their family members. By this time few Munda people were send to Tripura also and worked here in Tripura as tea garden laborers. Since then they were in Tripura and continue to work there in the tea gardens of Tripura.
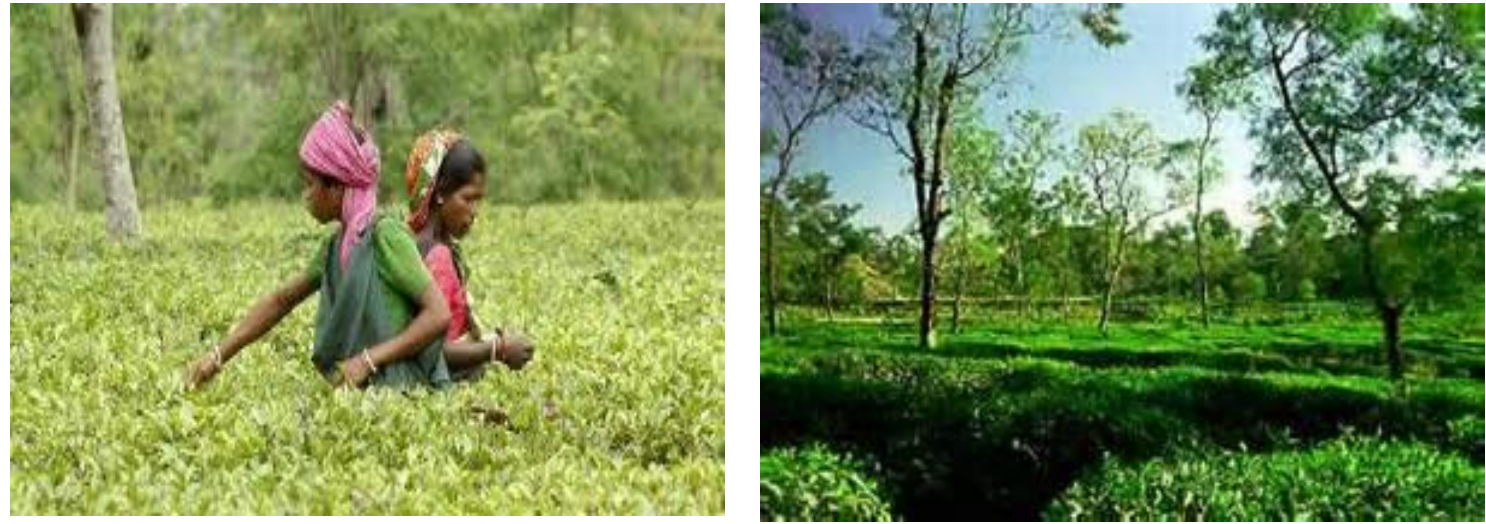

\section{Materials and Methods}

According to census report 2001 there are 12,416 Mundas in Tripura. Most of the Mundas are engaged themselves as tea garden labourers in the different tea estates of Tripura. In Tripura they are one of the important tribes out of 19 tribes recognized by the government of Tripura (Bera \& Bera-2009). They are hardworking, their female counterpart are also laborious. They all work together in the tea garden from almost dawn to dusk. They all do that for their livelihood and surviving.
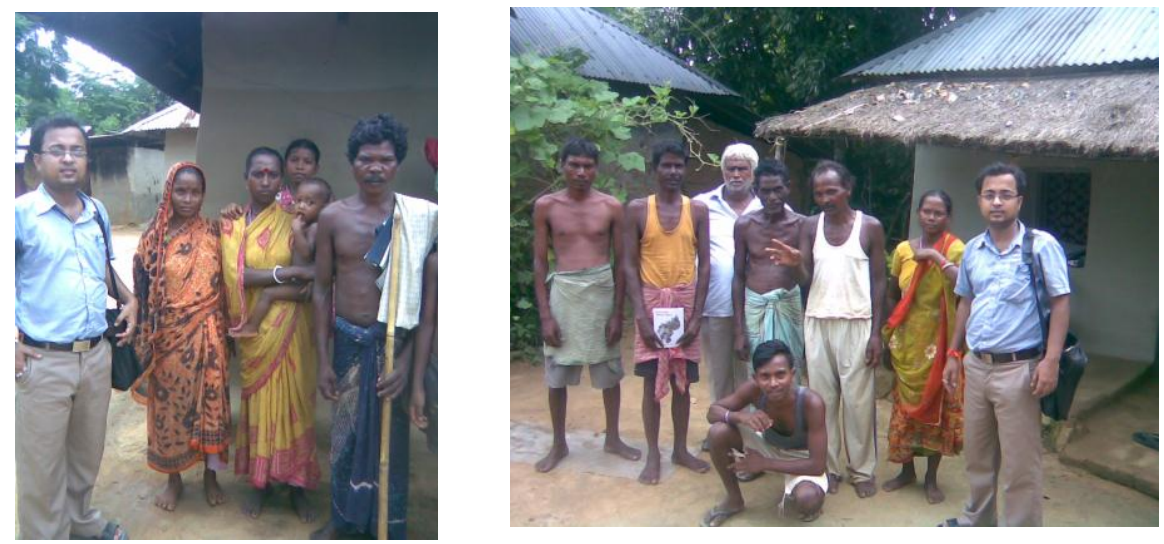

The present study has been conducted in the month of July 2012. The data were collected from Durga bari tea estates, Tufanialunga tea estates and Bagabari area through unstructured questionnaire, informal talks, personal conversation and interview. The data were collected from the respondents through purposive sampling method.

\section{Result and Discussion}

Aristotle once commented that, "Who exists outside the state by nature (and not by accident) is either beast or a God" In the context of modern society, the people get engaged themselves into the societal processes. But there are so many remain in the 


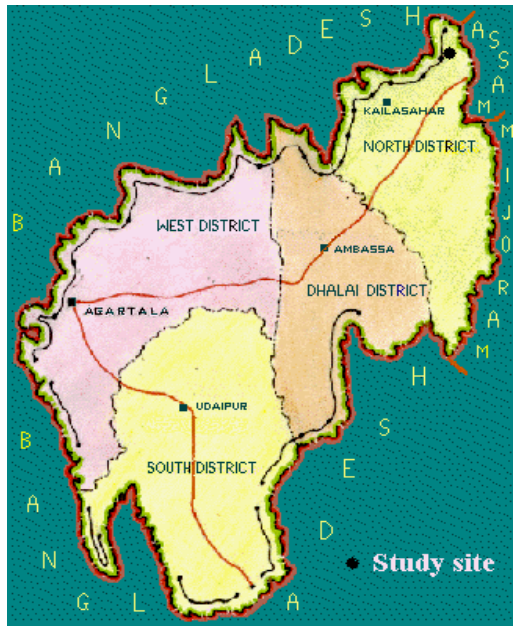

society who are not able to take part in the societal works; as a result of that they are depriving day by day from the democratic processes.

Present study deals with basically how the Munda people are alienated from different types of democratic processes. During the field visit some interesting as well as strange information has come out from the respondents. The Munda people of Tripura are living under the poverty line although some initiatives are being taken by the government. But these are not sufficient at all for their proper livelihood. Being a social animal we can not live without society and its surroundings. We take part in the process of every societal problem and try hard to solve it out. At the same time if a people of a society are not able to enjoy or exercise its own rights and liberties, with the passage of time they will be detached from the mainstream society.

Regarding the Munda people of Tripura, the special emphasis have been given to their alienation from different aspects mainly from democratic processes. It has been found that it becomes impossible for them to directly involve in the democratic processes like taking part in decision making process of the government. In local level also they can not put any effective impact upon the process. Although most of the Mundas are take part in casting their votes. But they do not aware of their social, economic and political rights. Most of the Munda people are less aware of the present condition of the state. During field survey strange information's have been found from few respondents that they have been forced to participate in the canvassing before the election, take part in party meeting and sometimes provoked them to cast their vote in favour of their own party. But the most important thing is before going to a meeting or related activities the member of the party took money from them for their bus or car fare. If any one from them is not capable to give the money the party members took $2 \mathrm{~kg}$ rice per head from them. This is a reality of their life.

So it can be assumed from the above observation that Munda people of Tripura are not so aware of their political rights and liberties. If they will not be able to know the present condition and not capable to realize the demand of the day or what actually an indispensable part of democratic society, the notion of democracy or the aims of it may be spoiled. So from that part it can be mentioned that the Munda people of Tripura are alienated from the political aspects of democracy.

The Munda people of Tripura are almost all the time busy with their daily routine work in the tea garden. So it becomes a tough job for them to know about the outer world. They even do not know of their identity, it means most of them replied that they do not know that they are Scheduled Tribe of Tripura as recognized by the government of Tripura. So from this it may be said that they are not aware of their identity i.e. the reservation policy of the government.

Even the rapid advancement of the society in $21^{\text {st }}$ century, Munda people are still lagging far behind than the other people of the society. They are quite conservatives. They always hold their own tradition, culture, customs although it is now in changing process. At present, the Indian democratic system is decentralized. It means power is not vested in to one hand. The sole source of all the power is people. But Munda people are not exercising those powers due to the lack of knowledge about the contemporary situation and structure of the society.

From another point of view the Munda people of Tripura do not enjoy or exercise the liberty and equality. In Indian constitution there has been an elaborate discussion and its implications are also taken into account. Article 14-18 of Indian constitution deals with right to equality. Article 19-22 also explains the term of right to freedom. Somehow it remains more theoretical rather than practical in respect of Munda people of Tripura as they are not enjoying the right to equality. Equal distribution is not there. Respondents deeply tried to focus on that direction. They uttered that we don't have any freedom because we cannot raise any question or do 
take any positive step for our development and we never go against the decision of the authority because of our incapability.

In that context it can be said that the notion of freedom do not put any positive impact on their condition. So they are alienated from this aspect also. The part IV of Indian constitution deals with Directive Principles of State Policy (Art 36-51); there are also exist many provisions basically for the social and economic welfare or development of the people (Ghai-2010). But from the study it has been revealed that the social and economic condition of Munda people in Tripura is worse. A minimum wages are paid to them after they work in the tea garden almost dawn to dusk. Although few facilities are given to them by the government but these are not sufficient for them at all.

It has also been explored that where the Munda people are inhabited or living, they never demand or claim for the ownership of their house. The authority usually gives those houses or places mostly within the garden area and it remains continue from generation to generation. That is why they never feel any economic freedom

In a democratic country like India, where constitution is the supreme law of the land and it deals with socio-economic and political life of the people through its various articles in respect to design a framework of environment where equality and equal distribution should be maintained. Although it has some loopholes of its proper execution and that should be rooted out from the society. As a result of that the people from every community of the society can be able to exercise and enjoy their rights and maintained the dignity of life.

\section{Concluding observation}

From the above study it is clear that Munda people of Tripura are not enjoying their democratic rights properly. The above study shows a gloomy picture of the alienation of Munda people in Tripura. Although they are migrated in Tripura but they should take part in democratic processes like participation in decision making process of the government, take part in the adult suffrage properly, express their own views and opinion freely, benefit should be given to them, proper usages of the government policy and they should take part in social activities.

In spite of all these things whatever is more needed is that they must be aware of their rights. As we know that democracy is of the people, by the people and for the people. So it can be mentioned that Mundas are also the people of India. It is their rights to have enjoyed or exercise their democratic rights and freedoms. In this way they will not be alienated from the democratic process. Over and above it must be mentioned here that all the provisions enlisted in Indian constitution for the development of the society. So it is the duty of our leaders to work for the development of the society, so automatically the condition of the Munda people must be enriched and developed. In that context positive attitude of the leaders, policy makers, government, NGOs is necessary for their development and in fact it is the demand of the day.

\section{Notes \& references}

[1] McLean, I and McMillan, A., 'Concise Dictionary of Politics' Oxford University Press, 2009.

[2] Directorate of census office, Agartala.

[3] Bera, G.K.and Bera, N. 'Echoes from the Hillocks: A Compendium on the Tribes of Tripura', Tripura Bani Prakashani, July 2009.

[4] Ghai, K.K., 'Indian Government and Politics' Kalyani Publishers, 2010.

[5] Photos of tea gardens-source-internet 